\title{
The Effect of Commercial Bank Lending Interest Rate on the Performance of the Residential Property Market in Kenya
}

\author{
Charles Gitiya Njoroge, Post Graduate Student \\ Prof. Willy M. Muturi, Lecturer \\ Dr. Oluoch Oluoch, Lecturer
}

Jomo Kenyatta University of Agriculture and Technology, Kenya

\begin{abstract}
The purpose of the study was to establish the effect of commercial bank lending interest rates on the performance of the residential property market in Kenya. Swelling of the residential property prices in Kenya vis a vis the commercial bank lending interest rates has ignited concerns about the sustainability of residential property market in Kenya. This study adopted a positivist philosophical attitude using causal research design. The study used secondary data from first quarter of 2005 to fourth quarter of 2018. The study conducted several test statistics and diagnostic tests in order to achieve the most optimal solution. Vector error correction model and auto-regressive distributed lag model were employed to test the hypothesis in the short run and long run respectively. The results found out that commercial bank lending interest rate had a negative effect on performance of residential properties in Kenya in both the short run and long run in line with loanable fund theory. The study has narrowed down the research gap brought about by the conflicting emprirical, theoretical and conceptual literature with regard to the effect of commercial bank lending interest rate on performance of residential property market in Kenya. To investor, the study recommends that need to negotiate for favorable loan terms especially interest rate given to them and/or their potential customers as it ultimatly influences their returns in the residential property market in Kenya both in the short run and long run.
\end{abstract}

Keywords: Commercial Bank Lending Interest Rates, Performance, Residential Property

\section{Introduction}

Escalation of the residential property prices in Kenya has raised questions about the affordability of residential property houses in Kenya 
(Murungi, 2014). This surge of residential property prices raises concern as to whether the housing development objective as per Kenya Vision 2030 and the big four agenda is attainable. The mean value for a residential property has gone up from 7.1 million in December 2000 to 31.4 million in December 2016, an increase of 342.3 per cent (HassConsult Limited, 2016). Yet, only one per cent of Kenyans in urban areas can afford a residential house of Kshs.5.7 million and above, five per cent can afford a home of Kshs. 3.9 million and above, twenty per cent can afford a home of Kshs.1.1 million and above (Kariuki \& Hassanali, 2014).

Even though commercial bank lending interest rate is expected to impact on residential property market performance, it is not clear how they affect the property market returns especially in Kenya. Notably various studies have discussed that commercial bank lending interest rate is important in examining the peformance of residential property market. However, the researchers have inconclusive findings on the direction of causation or the strength of the relationship that exists between the the two markets. There exist empirical differences, as discussed in the literature review section below, on the effect of commerncil bank interest rate on residential property market returns with some studies concluding on positive effects of interest rates, some on negative effects of interest rates while some maintain that interest rates have no effect on residential property market return.

\section{Literature Review}

Investors borrow to finance working capital needs and capital expenditures. According to Muriuki (2013) loanable funds theory assumes that interest rates are determined by supply of loanable funds and demand for credit. Therefore it can be explained that interest rates can dictate the amount of loans that residential property stakeholders can borrow at any given time which subsequently reflect on the profits made. Thus high profits insinuate capability to repay borrowed funds and vice-versa if profit is low due to high cost of capital. However despite this expectation as alluded by loanable fund theory the empirical literature is confounding.

Karamelikli (2016) undertook a study on the linear and nonlinear dynamics of housing price in Turkey between the years 2010 to 2016. In the paper non-linear autoregressive distributed lag (NARDL) model was employed to explore asymmetrical relations in the long-run. The effect of interest rate was found to have a positive sign in the study. This was explained by subtraction of inflation from the nominal interest rate to obtain the real interest rate variable. If nominal interest rate and inflation both have a negative effect on housing prices, and the inflation effect (in absolute terms) is greater than the nominal interest rate, then the long-run coefficient for the real interest rate could be positive. 
Rebi (2014) conducted a study on mortgage lending and house prices in Albania using a co-integrated analysis that was based on vector error correction model. The study aimed to empirically analyze the relation between housing prices and banks' financing in the long run. Rebi (2014) results show an insignificant relationship between interest rate and house prices. There are other researchers who also found out an insignificant relationship between interest rate and house prices (Crowe et al., 2010; Suljoti \& Hashorva, 2011; Ouma, 2011).

According to Crowe et al. (2010) lack of empirical evidence for the correlation of house prices to interest rates in many of the countries may be due to the inflationary pressures in the economy. More specifically global trade integration between countries (mainly developed and developing countries) has led to a rapid decline of import prices by counterbalancing the inflation of untradeable goods and, as result, may hide the relationship/impact of the interest rate on houses prices (non-tradable goods).

Muriuki (2013) carried out a study on the effect of interest rates volatility on the growth of real estate market in Kenya in the period 2008-2012. The study observed that the interest market experienced low volatility. Thus, volatility in the interest market was predictable, at least in the short run. The recommendation made was that the investors should consider investing in the real estate market despite the erratic interest rates.

Muli (2013) carried out a study on the assessment of the factors affecting the growth in real estate investment in Kenya for the period 2000 to 2012. The study adopted quantitative and descriptive research design and employed multiple regression model. The study found that there was a strong inverse relationship between interest rates and house prices. That is, house prices rise when interest rates drop. As most purchases are done on credit, interest rates are an additional cost to home buyers. There are also other researches that found a negative relationship between interest rates and housing prices, (Ayuso, Perez \& Saurina, 2004; Egert \& Mihaljek, 2007; Kim, Lee \& Kim, 2011; McQuinn \& O'Reilly, 2008; Muli, 2013; Ong \& Chang, 2013; Sutton, 2002; Tse, Rodgers \& Niklewski, 2014; Xu \& Chen, 2012).

Even though there are several studies that have found a negative relationship between interest rate and performance of residential property market (Muli, 2013), there are studies that have indicated positive relationship (Karamelikli, 2016), while others have indicated insignificant relationship (Crowe et al., 2010; Rebi, 2014). Therefore, to understand this issue better, this study sought to clearly examine the effect of commercial bank lending interest rate on residential property market performance in Kenya. Thus, the study aimed at testing the following hypothesis:

H0: Commercial bank lending interest rate has no significant effect on the performance of the residential property market in Kenya. 


\section{Methodology}

This study mirrored the philosophy of positivism which according to Bevir (2010) is a philosophical attitude that emphasis on the need for researchers to trust in science, opposition to metaphysics and unified science. The study also reflected causal research design as the interest was in assessing the relationship between commercial bank lending interest rate and residential property market in Kenya. According to Kumar (2014) the causal research design helps to isolate or quantify the effect of different sets of variables influencing the dependent variable. It is conducted when researchers want to explore the extent to which changes in one variable are reflected in changes in the other variable (Creswell \& Garrett, 2008).

The population of this study was 56 market quarter observations from 2005 to 2018 of the commercial bank lending interest rate and quarterly house price index of residential property market for secondary data. According to Pandey and Pandey (2015) research studies should identify schedules and procedures to be used for acquiring secondary data and recording it accurately. Therefore, a data collection sheet was utilized to organize the collected data. This data was authentic and reliable since it was secondary data that was collected by credible agents and published reports.

Descriptive statistics was presented to test the normality of the data. In addition the study purposed to carry out an autocorrelation test of the series under study. Akter (2014) assert that if the usual testing procedure is executed despite autocorrelation problem whatever the conclusions is made may be misleading. The study also purposed to carry out a heteroskedasticity test of the secondary data set. Since, as stipulated by Engle (1982) the problem caused by heteroskedasticity is that it causes the mean and the variance of a variable to evolve over time. This makes any inference from such variable to be erroneous.

Kumar (2014) assert that hypothesis is an assumption, suspicion, assertion or an idea about a phenomenon. Creswell (2013) note those hypotheses are predictions the researchers make about the expected outcomes of relationship among variables. Testing hypothesis on the other hand employs statistical procedures in which the investigator draws inferences about the population from the study sample. According to Gujarati and Porter (2009) several criteria are used for selection of a model. These include R-squared, adjusted R-squared, F-statistic, Akaike's information criteria, Schwarz's information criterion and Hannan-Quinn information criteria. No one of these criteria's is necessarily superior to the others. The study therefore employed these statistics to arrive at conclusive inference. In particular the study used tstatistics and the p-value to test the significance of the null-hypothesis for any type of individual test. The five per cent level of significance was compared with the p-value and significance of the predictor variable(s) concluded if the 
latter is less than five per cent (Filho et al., 2013). P-value is the exact lowest probability of rejecting the null hypothesis when it is true (Gujarati \& Porter, 2009).

Vector error correction model (short-run) and auto-regressive distributed lag (long-run) model were employed to test the hypothesis. According to Baum (2013) VECM are employed when the time series appear to be first-difference stationary with their levels exhibiting unit root or nonstationary behaviour. Conventional regression estimators, including VARs, have good properties when applied to covariance-stationary time series, but encounter difficulties when applied to nonstationary or integrated processes. Baum (2013) further states that the VECM has an advantage as the resulting VAR from VECM representation has more efficient coefficient estimates. Further, according to Tserkezos (2013) it has a better interpretation of short run relationship between variables that have a co-integration relationship thus VECM was employed to measure the short-run relationship of the series under study.

Applying the VAR(4) model we create a matrix $\mathrm{Zt}=[\mathrm{RPMt}, \mathrm{INRt}$,$] that has$ four lags as follows:

$$
\mathrm{Z}_{\mathrm{t}}=\mathrm{A}_{1} \mathrm{Z}_{\mathrm{t}-1}+\mathrm{A}_{2} \mathrm{Z}_{\mathrm{t}-2}+\cdots+\mathrm{A}_{4} \mathrm{Z}_{\mathrm{t}-4}+\mathrm{u}_{\mathrm{t}}
$$

The VAR(4) model can be reformulated in a vector error correction model as follows:

$$
\Delta \mathrm{Z}_{\mathrm{t}}=\prod_{1} \Delta \mathrm{Z}_{\mathrm{t}-1}+\prod_{2} \Delta \mathrm{Z}_{\mathrm{t}-2}+\prod_{4} \Delta \mathrm{Z}_{\mathrm{t}-3}+\prod \mathrm{Z}_{\mathrm{t}-1}+\mathrm{u}_{\mathrm{t}}
$$

where the matrix $\Pi$ contains information relating to commercial bank lending interest rate and performance of residential property market in Kenya. We can decompose $\Pi=\pi \beta^{\prime}$ where $\pi$ will include the speed of adjustment to equilibrium coefficients, while $\beta^{\prime}$ will be the matrix of coefficients. Then, the term $\beta^{\prime} Z_{\mathrm{t}-1}$ term will be the error correction term.

Autoregressive distributed lag (ARDL) model was employed to measure longrun relationship of commercial bank lending interest rate and performance of residential property market in Kenya. According to Nkoro and Uko (2016) ARDL co-integration technique does not require pre-test unlike other techniques. Thus ARDL co-integration technique is preferable when dealing with variables that are integrated of different order or combination of both. ARDL co-integration technique is robust when there is a single long-run relationship between the underlying variables in a small sample size (30 observations to 80 observations). The long run relationship of the underlying variables is detected through the F-statistic (Wald test) i.e. when the F-statistic exceeds the critical value band. The major advantage of the ARDL cointegration technique, as explained by Nkoro and Uko (2016), lies in its identification of the co-integrating vectors where there are multiple cointegrating vectors. The ARDL approach has the additional advantage of 
yielding consistent estimates of the long-run coefficients that are asymptotically normal, thus ARDL was employed to test the long run relationship of the variables under study. The research employed the Eviews econometric software and room was given for the econometric software to automatically determine the lag structure that was employed in the ARDL. All the same, the general ARDL $(\mathrm{p}, \mathrm{q})$ model employed was as follows:

$$
\begin{gathered}
\mathrm{RMP}_{\mathrm{t}}=\mathrm{A}_{1} \mathrm{RMP}_{\mathrm{t}-1}+\cdots \mathrm{A}_{\mathrm{p}} \mathrm{RMP}_{\mathrm{t}-\mathrm{p}-1}+\mathrm{B}_{0} \mathrm{INR}_{\mathrm{t}}+\mathrm{B}_{1} \mathrm{INR}_{\mathrm{t}-1} \\
+\cdots \mathrm{B}_{\mathrm{q}} \mathrm{INR}_{\mathrm{t}-\mathrm{q}-1}+\mathrm{u}_{\mathrm{t}}
\end{gathered}
$$

Where $u_{t} \sim \operatorname{iid}(0, \sigma 2)$

The long run dynamic (equilibrium effect will be determined as follows)

$$
\frac{\partial Y_{T}}{\partial X t}=\frac{B_{0}+B_{1}+B_{2} \cdots+B_{q}}{1-A_{1}-A_{2} \cdots-A_{p}}
$$

\section{Findings and Discussion}

Table 1 presents secondary descriptive statistics for the variables under study.

Table 1: Summary statistics for the secondary data set

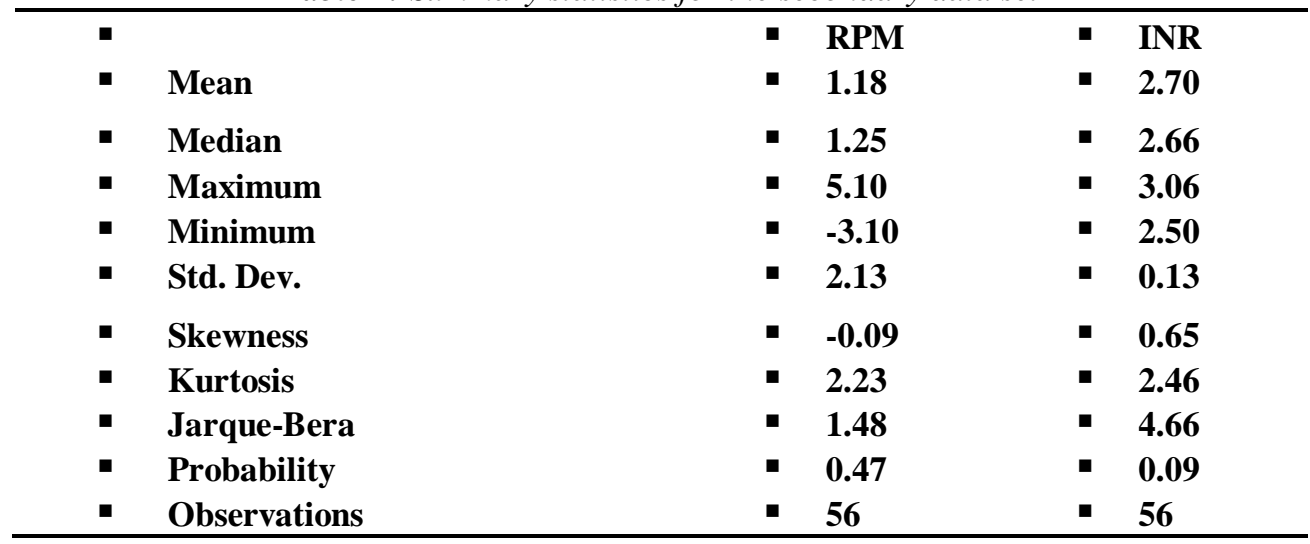

Residential property market performance (RPM) was measured by the percentage change in quarterly house price index. The positive mean of 1.18 shows that on average there was an increase in residential property market prices by 1.18 per cent over and above the previous quarter price. The standard deviation of 2.13 indicates that even though there was a noticeable increase in residential property prices over time, the fluctuations in percentage change between one period and another were considerable. Residential property market performance portrays a negative skewness -0.09 indicating a left tail of distribution that is approximately symmetric (Brown, 2011). Kurtosis value was 2.23 which is less than 3 , which shows that the variable is platykurtic. The platkurtic observation of residential property market performance shows that this market was considered less risky than would be a normal market in Kenya. This series had a Jarque-Bera value of 1.48 and its p-value of 0.47 shows that 
the residential property market performance had no significant departure from normality.

Commercial bank lending interest rate (INR) was measured by natural log of the commercial banks' weighted average interest rates over the period of study. Positive commercial bank lending interest rate mean of 2.70 shows that the mean interest rate for the period under study was averaging to 14.8797 per cent. It is good to note that the period under study covers both pre interest rate capping period in Kenya and post interest rate capping. According to Ochieng (2018) the interest rate cap law came into effect in Kenya on 14th September 2016 with an aim of making credit affordable to the 'common man'. The interest rate cap law helped to reduce the volatility of the lending interest rate and this can be observed by the low standard deviation of 0.13 that was associated with this series. Nevertheless, the gap between maximum and minimum value (Maximum; 3.06, Minimum; 2.50) of commercial bank interest rate indicates that there was a considerable difference between low and high commercial bank lending interest rate values. This was mainly because of the volatility of interest rate before the interest law came into effect and the regulation of the interest rate after the law was effected.

Commercial bank lending interest rate portrays a positive skewness of 0.65 indicating a right tail of distribution which indicates that variable was moderately skewed (Brown, 2011). According to Ivanoski, Stojanovski, and Narasanov (2015) since this distribution is positively skewed, there is higher probability of large positive increase in commercial bank lending interest rate than negative decreases in interest rate. Kurtosis value was 2.46 which is less than 3. The platkurtic observation of commercial bank lending interest rate shows that the price of lending finances (money) in Kenya has less random events and this can be explained by the interest rate cap law of 2016 that has eased the predictability of commercial lending interest rate in Kenya (Ochieng, 2018). Furthermore, Jarque-Bera value of 4.66 and a p-value of 0.09 shows that the variable had no significant departure from normality as explained by Dettling(2017). Commercial bank lending interest rate in Kenya was considered to be fairly normally distributed.

Table 2: VEC residual serial correlation LM test of commercial bank interest rate and residential property market performance in Kenya

VEC Residual Serial Correlation LM Tests, Null Hypothesis: no serial correlation at lag order h, Sample: 2005Q1 2018Q4, Included observations: 52

\begin{tabular}{lll} 
Lags & LM-Stat & Prob \\
\hline & & \\
1 & 2.678694 & 0.6129 \\
2 & 1.672175 & 0.7958 \\
3 & 5.018963 & 0.2854 \\
4 & 4.387033 & 0.3562
\end{tabular}

Probs from chi-square with $4 \mathrm{df}$. 
Table 2 presents the results for the test of serial correlation. The test results failed to reject the null hypothesis of the model. The null was not rejected on the basis that the p-value of the chi-square (langrange-multiplierLM) was statistically insignificant for all the four quarters. In particular for lag one the LM-Statistic was 2.678694 and p-value was 0.6129. This shows that there was no serial correlation at lag one since the $\mathrm{p}$-value was above 0.05 level of significance. The same was observed for lags two to four where their p-vlaues were above the 0.05 level of signficance. This implied absence of serial correlation for the time series with four lags.

Table 3: VEC residual heteroskedasticity test of commercial bank interest rate and residential property market performance in Kenya

VEC Residual Heteroskedasticity Tests: No cross terms (only levels and squares), Sample: 2005Q1 2018Q4, Included observations: 52

Joint test:

Chi-sq df Prob.

$\begin{array}{lll}44.76823 & 42 & 0.3564\end{array}$

Individual components:

\begin{tabular}{lccccc} 
Dependent & R-squared & $\mathrm{F}(14,37)$ & Prob. & Chi-sq(14) & Prob. \\
res1*res1 & 0.11575 & 0.345954 & 0.9819 & 6.018981 & 0.9660 \\
res2*res2 & 0.23727 & 0.822152 & 0.6416 & 12.33818 & 0.5792 \\
res2*res1 & 0.37409 & 1.579628 & 0.1317 & 19.45316 & 0.1483 \\
\hline
\end{tabular}

Table 3 presents the result of residual heteroskedasticity test. From the above results the presence of heteroskedasticity was rejected since the pvalues for the joint test were statistically insignificant. In the individual components the presence of heteroskedasticity was also rejected.

Table 4: VECM result of commercial bank interest rate and residential property market

\begin{tabular}{lr}
\hline Cointegrating Eq: & CointEq1 \\
RPM(-1) & 1.000000 \\
INR(-1) & -0.506656 \\
& $(0.12894)$ \\
& {$[-3.92936]$} \\
Error Correction: & \\
CointEq1 & -0.648197 \\
& $(0.16655)$ \\
R-squared & {$[-3.89191]$} \\
Adj. R-squared & 0.438843 \\
F-statistic & 0.364022 \\
Log likelihood & 5.865242 \\
Akaike AIC & -96.73156 \\
Schwarz SC & 3.989675 \\
\end{tabular}

Table 4 presents the vector error correction model results used to measure the short run effect of commercial bank lending interest rate on the 
performance of residential property market in Kenya. From the results, in the short run, commercial bank lending interest rate had a negative effect on the performance of residential property market in Kenya. The regression coefficient of interest rate had an associated t-statistic value of -3.92936 which was statistically significant. The result also shows the error correction term value of -0.648197 . This value showed that the speed of adjustment toward equilibrium value was $64.8 \%$. The associated t-statistic value of -3.8919 was also statistically significant. Looking at the R-squared it shows that variations in the commercial bank lending interest rates in the short run explains 43.8843 per cent of the performance of residential property market. The F-statistic of 5.865242 shows that the model was significant.

Table 5: ARDL long run form result of commercial bank interest rate against market performance of residential property market

ARDL Cointegrating And Long Run Form: Dependent Variable: RPM: Dynamic regressors (4 lags, automatic), INR: Sample (adjusted): 2006Q1 2018Q4 : Included observations: 52 after adjustments: Maximum dependent lags: 4(Automatic selection): Model selection method: Akaike info criterion (AIC): Selected Model: $\operatorname{ARDL}(4,0)$

Long Run Coefficients

\begin{tabular}{|c|c|c|c|}
\hline Variable & Coefficient & Std. Error & t-Statistic \\
\hline INR & -0.523524 & 0.136055 & -3.847892 \\
\hline R-squared & 0.358173 & Mean dependent var & 1.375192 \\
\hline Adjusted R-squarec & d0.303549 & S.D. dependent var & 2.042317 \\
\hline S.E. of regression & 1.704388 & Akaike info criterion & 3.995501 \\
\hline Sum squared resid & 136.5322 & Schwarz criterion & 4.183121 \\
\hline Log likelihood & -98.88303 & Hannan-Quinn criter. & .4 .067430 \\
\hline
\end{tabular}

Durbin-Watson stat 1.937633

Cointeq $=$ RPM $-(-0.523524 * I N R)$

Table 5 presents the results of autoregressive distributed lag (ARDL) model that was employed to measure the effect of commercial bank lending interest rate on the performance of residential property market in Kenya in the long run. This results shows that in the long run commercial bank lending interest rate had a negative effect on the performance of residential property market in Kenya. The regression coefficient of commercial bank lending interst rate had an associated t-statistic value of -3.847892 which was statistically significant since the associated probability value was 0.0004 . From the R-squared it can be observed that in the long run variations in commercial bank lending interest rates explained 35.8173 per cent of performance of residential property market in Kenya. Durbin-Watson statistics of 1.937633 shows absence of first-order serial correlation in the error terms.

Applying the loanable fund theory to the findings of this study, both in the short run and long run form, shows that interest rate is one of the key components of residential property market performance i.e. interest rate influence the amount of loans that investors in the residential property market 
in Kenya are ready and able to borrow at any given time which consequently reflect on the performance of the residential property market. The findings of this study indicate that low interest rate should increase performance of residential property market in both the short run and long run. Applying loanable fund theory then very low interest rate will discourage savings thus ultimately there will be a balance/equilibrium between interest rate and residential property market performance.

Similar findings were observed by Karasu (2015) who carried out a study to determine whether there was a real estate bubble in Turkey where house prices were increasing rapidly. Karasu (2015) study used a 10 years long data set (2005-2014). Karasu (2015) observed significant decreases in housing interest rates could be credited to the eased condition of credit in Turkey in the late 2000s. This deregulation seemed to strengthen the demand for housing. This led to increase in housing loans in Turkey as houses seemed to be less risky compared to other alternative investment instruments.

This study result differed with Muriuki (2013) who carried out a study on the effect of interest rates volatility on the growth of real estate market in Kenya in the period 2008-2012. Muriuki (2013) sort to show case this effect by showing how growth of real estate market is affected by the interest rates volatility by use of a regression model. Muriuki (2013) found out that the demand for real estate in Kenya was growing exponentially defying fundamentals such as high interest rates. The study owed this situation to the price inelastic demand for housing owing to economic disparity in the Country and the burgeoning middle-income population.

Different from the findings of this study was Pillaiyan (2015) study that investigated the macroeconomic drivers of house prices in Malaysia using vector error correction model over a fifteen year period 1999-2013. Macroeconomic factors investigated were real GDP, bank lending rate, consumer sentiment, business condition, money supply, number of loans approved, stock market and inflation. Pillaiyan (2015) found that bank lending rate had an insignificant effect on residential property market performance. The results hinted at the potential of the housing price bubble in Malaysia. According to Pillaiyan (2015) it is wothwhile for investors to take caution of very low interest rates as they could fuel a bubble in price of residential property market.

From the findings of this study in the Kenyan context commercial bank lending interest rate is important in the performance of the residential property market. This is because interest rate affect the aggregage demand and aggregate supply position of the residential property market. The rising or falling of interest rate therefore influences the expectations and plans of investors in this particular market in Kenya. Changes in interest rate, as per the findings of this study, will affect the residential property market consumers 
views and purchasing decisions ultimately affecting the performance of the residential property market.

\section{Conclusion}

The research set to investigate effect of commercial bank lending interest rate on the performance of the residential property market in Kenya. The descriptive statistics were used to determine whether the series (interest rate and performance of residential property market) were normally distributed. The results showed that the variables were slightly skewed. The kurtosis results also showed that the normality assumption were slightly violated. The Jarque-Bera test indicated that the variables had no significant departure from normality.

From the models used, commercial bank lending interest rate had a negative and significant effect on performance of residential property market in Kenya in the short run as well as the long run. This was supported by the loanable fund theory since investment in this market was dependent on the interest rate offered.

The study concludes that the commercial bank lending interest rate has a negative effect on the performance of the residential property market in Kenya. This shows that commercial bank lending interest rate has an explanatory power on performance of the residential property market in Kenya. The conclusion was that commercial banks interest rate is a relevant factor in explaining the performance of the residential property market in Kenya. Results from this study reveals that returns in residential property market increase when interest rate drop this implies that most purchases are done on credit, thus interest rates are an additional cost to residential property buyers. The loan installment amount reveals the amount a residential property buyer can afford. The monthly loan payment installment is governed by the loan amount, interest rate and duration of the loan. A lower loan interest rate will result in a lower monthly payment. The finding of this study implies that purchasing decisions are more sensitive to the nominal interest charged in the monthly payments.

For investors who purpose is to use debt to finance their investment in residential property market, the study recommends that they should consider lenders with favorable terms as this will ultimately influence their investment performance. Investors should also consider partnering with lenders who will offer competitive mortgage terms to their prospective clients. This also explains where many investors employ the use of off-plan sells to finance their investments. The study also recommends that the Government of Kenya and other regulators should put in place mechanisms that will help them monitor the fluctuations in the commercial bank lending interest rates. The capping on 
interest rate in Kenya is expected to partly work on stabilizing the property market performance and also forms an area of interest for further studies.

\section{References:}

1. Akter, J. (2014). Bootstrapped durbin-watson test of autocorrelation for small samples. ABC Journal of Advanced Research, 3(2), 23042621.

2. Ayuso, J., Pérez, D., \& Saurina, J. (2004). Are capital buffers procyclical? Evidence from Spanish panel data. Journal of Financial Intermediation, 13(2), 249-264.

3. Baum, C. F. (2013). VARs, SVAR and VECM models. Boston: Boston College.

4. Bevir, M. (Eds.). (2010). Encyclopedia of political theory: A-E. New Delhi, India: Sage Publications Ltd.

5. Brown, S. (2011, June). Measures of shape: skewness and kurtosis. Retrieved November 2018, from Tomkins Cortland Community College: http://www.tc3.edu/instruct/sbrown/stat/shape.htm

6. Creswell, J. W. (2013). Research design: Qualitative, quantitative, and mixed methods approaches. Sage Publications Ltd.

7. Crowe, C., Dell'Ariccia, G., Igan, D., and Rabanal, P. (2011), Policies for Macro - financial Stability: Options to Deal with Real Estate Booms, IMF Staff Discussion Note, SDN/11/02.

8. Dettling, M. (2017). Statistical analysis of financial data. Zurich: Swiss Federal Institute of Technology.

9. Égert, B., \& Mihaljek, D. (2007). Determinants of house prices in central and eastern Europe. Comparative Economic Studies, 49(3), 367-388.

10. Engle, R. F. \& Granger, C. W. J (1987). Co-integrated and corrected: Representation estimation, and testing. Econometrica, 55(2), 251-276.

11. Engle, R. F. (1982). Autoregressive conditional heteroscedasticity with estimates of the variance of United Kingdom inflated. Econometrica, 50(4), 987-1008.

12. Filho, D. B., Paranhos, R., Rocha, E. C., Batista, M., Silva, J. A., Santos, M. W., et al. (2013). When is statistical significance not significant? Brazilian Political Science Review, 7(1), 31-55.

13. Gujarati, D. N., \& Porter D. C. (2009). Basic econometrics (5th ed). New York: McGraw-Hill/Irwin inc.

14. HassConsult Limited. (2016, Fourth Quarter). Property prices and rentals in satellite towns record the lowest annual growth rate in 8 years. The Hass Property Index - House Price Index, 1-5. 
15. Ivanoski, Z., Stojanovski, T., \& Narasanov, Z. (2015). Volatility and kurtosis of daily stock returns at MSE. UTMS Journal of Economics, 6(2) 209-221.

16. Jarque, C. M., \& Bera, A. K. (1987). A test for normality of observations and regression residuals. International Statistical Review, 163-172.

17. Karamelikli, H. (2016). Linear and nonlinear dynamics of housing price in Turkey. Ekonomia, 46, 81-98. doi:10:17451/eko/46/2016/238.

18. Karasu, M. N. (2015). Understanding real estate bubbles: an analysis of the recent trends in the Turkish housing market. Turkey: Middle East Technical University.

19. Kariuki, C., \& Hassanali, S. (2014). Mortgage market energized by new rates and policies. The Hass Property Index, Mortgage Report, pp. $1-4$.

20. Kim, S., Lee, S., \& Kim, J. (2011). Relationship between the financial crisis of Korean construction firms and macroeconomic fluctuations. Engineering, Construction and Architectural Management, 18(4), 407422, doi: 10.1108/09699981111145844

21. Kothari, C. R. (2004). Research methodology: Methods and techniques, $\left(2^{\text {nd }}\right.$ ed.). Mumbai, India: New Age International (P) Limited, Publishers.

22. Kumar, R. (2014). Research methodology: A step-by-step guide for beginners. New Delhi, India: Sage Publications Ltd.

23. McQuinn, K., \& O'Reilly, G. (2008). Assessing the role of income and interest rates in determining house prices. Journal of Economic Modelling, 25(3), 377-390.

24. Muli, N.F. (2013). An assessment of the factors affecting the growth in real estate investment in Kenya (Master's thesis). Nairobi: University of Nairobi.

25. Muriuki, A. M. (2013). The role of central bank rate on commercial banks profitability in Kenya. Nairobi: University of Nairobi.

26. Murungi, R. K. (2014). An investigative study on the factors causing price changes of residential houses in Nairobi over the period 20082012. Nairobi: The University of Nairobi.

27. Nkoro, E., \& Uko, A. K. (2016). Autoregressive distributed lag cointegration technique: application and interpretation. Journal of Statistical and Econometric Methods, 5(4) 63-91.

28. Ochieng, J. (2018). Interest rate cap two years on: Outcomes for Kenya's economy. Retrieved 2019, from The Kenya Institute for Public Policy Research and Analysis: http://kippra.or.ke 
29. Ong, T. S., \& Chang, Y. S. (2013). Macroeconomic determinants of Malaysian housing market. Journal of Human and Social Science Research, 1(2), 119-127.

30. Pandey \& Pandey (2015), Research methodology: Tools and techniques. Romania, European Union: Bridge Centre Publishers.

31. Pillaiyan, S. (2015). Macroeconomic drivers of house prices in Malaysia. Canadian Social Science, 11(9), 119-130. doi:10.3968/7482.

32. Rebi, E. (2014). Mortgage lending and house prices in Albania. A cointegrated analysis based on VECM. Eastern Journal of European Studies, 5(1).

33. Suljoti E., Hashorva G. (2011), House Prices and Mortgage Loan in Tirana, Economic Bulletin Bank of Albania.

34. Sutton, G. D. (2002). Explaining changes in house prices. Bank for International Settlements [BIS] Quarterly Review, 32, 46-60.

35. Tse, C. B., Rodgers, T., \& Niklewski, J. (2014). The 2007 financial crisis and the UK residential housing market: Did the relationship between interest rates and house prices change? Economic Modelling, 37, 518-530.

36. Tserkezos, E. D. (2013). Vector error correction models. Macedonia: University of Macedonia.

37. Xu, X. E., \& Chen, T. (2012). The effect of monetary policy on real estate price growth in China. Pacific-Basin Finance Journal, 20(1), 6277. 